\title{
Pre-service Teachers' Perceptions About a Course Including Conversation Practice with Teacher Training Students from Abroad
}

\section{Wendy Tada}

\author{
Hyogo University of Teacher Education \\ https://doi.org/10.37546/JALTTLT45.2-1
}

\begin{abstract}
This study aimed to identify pre-service teachers' views and experiences after participating in a compulsory communication course including impromptu conversation practice with exchange students as well as to make recommendations for future courses by understanding their views through their prior experiences. Their past experiences are extremely likely to influence their ability to communicate with assistant language teachers (ALTs) in Japanese schools especially in relation to impromptu conversations. Thus, in 2019, a communication course was developed for first-year pre-service teachers that included impromptu conversation practice for three lessons with six teacher training students (TTSs) on MEXT scholarships and two exchange students. After the course, Japanese students completed a survey and the results indicated that due to the conversation practice many students grasped a better understanding of their language ability, gained motivation to communicate with foreigners, and most students felt three or more lessons are suitable for such practice. The results underscore the need for classes focusing on impromptu conversation practice to better prepare pre-service teachers to work with ALTs.
\end{abstract}

本研究は、交換留学生と即興で行う会話練習を含む、必修のコミュ二 ケーションコースを受講した教育実習生たちの経験や見解等を調査し、 その調査結果から得られる教育的示唆を明らかにすることを目的として いる。教育実習生たちの事前の学習経験は、実際の教育実習で彼らが外 国語指導助手 (ALT) とコミュニケーションをとることができる能力、特 に即興でやりとりすることができる能力に、きわめて大きな影響を与える と予想される。それゆえ、筆者は、2019年に交換留学生2人と日本の文部 科学省 (MEXT) の資金援助を受けている教員研修留学生(TTS)6人が参 加する3コマ (1コマ90分) の会話レッスンを含むコミュニケーションコー スを開設し、同コ一スに参加した1年生の教育実習生27人に対して調査を 行った。その調査結果によれば、留学生との会話練習は、多くの学生に自 分の言語能力をより良く理解させ、外国人とコミュニケーションを図ろう とする意欲を向上させるものであった。また、大分部の学生は3コマ以上 の会話レッスンが適切であると感じていた。この調査結果は、ALTと将来 一緒に授業をする教育実習生のレベルを向上させるためには、即興で行 う会話練習に焦点を当てたクラスが必要であることを強く示している。

\section{Current Level of English Teachers' Communicative Skills}

Due to changes to the Course of Study Guidelines (MEXT, 2018) and the introduction of additional points for English skills by 42 boards of education when they recruit new elementary school teachers
(Minetoshi \& Doi, 2017), pre-service and in-service teachers have been encouraged to re-examine their English proficiency levels. Illustrating this trend, a 2016 study reported that $32 \%$ of junior high school English teachers and 62\% of high school English teachers had passed Grade Pre 1 level of Eiken (CEFR B2 level), indicating a small increase compared to the previous year (MEXT, 2017a). However the same study also showed that, across all types of high school English courses, an average of roughly $55 \%$ of teachers used English for less than half of their class time, and only $11 \%$ of them used it for more than three quarters of the time (MEXT, 2017a). In short, greater teacher test proficiency does not necessarily correspond to an increase in in-class English usage. To this end, what Japanese classroom teachers really need is teacher training programs that provide opportunities to use English as a medium of communication rather than a mere target of instruction.

Currently, English teacher training courses mainly aim at providing pre-service teachers with teaching expertise. However, Tsuji and Swanson (2017) claim that for many non-native teachers "acquiring a sufficient level of speaking proficiency is a primary issue" (p. 131). They go on to suggest that teachers need to practice improvisation to develop speaking skills, and recent research (e.g., Yoshida et al., 2020) has tended to focus on developing impromptu conversation skills of students, mainly due to the new guidelines (MEXT, 2017b) that clearly require teachers to include impromptu communication practice from junior high school. Consequently, English teacher training should also include more opportunities to practice impromptu communication, especially to reduce anxiety and to increase teachers' confidence to speak in front of classes with ALTs.

\section{Pre-service Teachers' Opportunities to Practice Impromptu Communication}

Unlike students in other types of courses, pre-service teachers of English have a genuine need to 
use English to communicate with ALTs. However, without opportunities to practice their English use, teachers at various levels often lack confidence, feel anxious about impromptu conversations, and worry about the appropriateness or accuracy of their English (Tanabe, 2011), and such factors can become language barriers that make it difficult to establish good team teaching relationships (Fukuda et al., 2013). Since communicative language teaching (CLT) techniques are often not effectively implemented in English classrooms in Japan (Rushton, 2019), students often have limited opportunities to regularly experience both controlled and free communication practice within their classes, for a variety of reasons, such as pressure to complete textbook content, frequent testing, and language practice focusing on accuracy more than fluency. This means impromptu communication practice is often either relegated to short tasks not linked to the main content of English classes or else focused on in classes with native English-speaking teachers, rather than implemented as a regular activity aimed at fostering impromptu speaking skills. Thus, pre-service teachers need to learn ways to teach communication including impromptu conversation practice and to experience impromptu conversation practice either during their education courses or by studying abroad.

\section{Japanese Students' Interest in Studying Abroad}

Opportunities to communicate with English speakers occur not only within courses but also during study or travel abroad. According to the OECD, only $1 \%$ of university students from Japan study abroad (OECD , 2018), and this percentage is not increasing even with the 2013 launching of the government-sponsored Tobitate! (Leap for Tomorrow) Study Abroad Initiative (MEXT, n.d.). This may be linked to a variety of factors, such as safety concerns, the perceived value of studying abroad, financial limitations, timing of job hunting, views of educators, and language ability concerns (Kobayashi, 2018). However, many universities have invested an increasing amount of time in developing partnerships with universities abroad, international exchange programs, special events, and language exchange opportunities within their universities to support the government's aim to internationalize universities (MEXT, 2012). One of the best ways to ensure that large numbers of students experience real opportunities to communicate in English is by including opportunities within compulsory courses. If conversation practice with students from abroad within compulsory communication courses increases, a larger number of pre-service teachers will be able to experience more spontaneous communication practice in English even if they are unable to study abroad.

\section{TTS Exchange Students Doing Research in Japan with Teaching Experience}

Every year MEXT provides scholarships for graduate-level exchange students to carry out research at approximately 50 designated universities in Japan. These exchange students are referred to as teacher training students (TTSs). TTSs are required to have at least five years of experience as teachers or as teacher trainers in their home countries. They must also be under 35 years of age as well as meet certain other conditions (MEXT, 2019). The MEXT scholarship allows them to attend a Japanese university to conduct research on a predetermined research topic. Since one of the aims of the scholarship is to "foster human resources who will become a bridge of friendship between the grantee's country and Japan" (MEXT, 2019, p. 1), these visiting students have the potential not only to build relationships with pre-service teachers but also to become valuable contacts for arranging cultural exchange activities after returning to their home countries. Hence, due to their knowledge, experience, teacher-like qualities, the potential to be useful future contacts for international exchange, and proficiency in English, TTSs are ideal interlocutors to interact with Japanese students studying to be teachers. An additional benefit is that many of these exchange students come from developing countries that have diplomatic relations with Japan. For Japanese students, who are often unaware of the education systems in those countries, such an opportunity enables them to learn about different education systems, which fosters more authentic communication. However, the potential to include TTSs in compulsory English communication courses has been surprisingly overlooked. Unlike regular exchange students, who must earn a set number of credits, TTSs have more flexible schedules, which means they can join a limited number of English communication courses with relatively little difficulty. On the other hand, arranging their participation in courses does require the cooperation of university staff who can inform TTSs of such courses. With these factors in mind, the aim of the present study was to design and implement a compulsory communication English course with mainly TTSs and to determine its impact on pre-service teachers' communication skills and on their views of engaging in impromptu English speaking practice with exchange students. 


\section{Research Questions}

This study was guided by three research questions:

RQ1. What background factors regarding Japanese pre-service teachers should be known before developing conversation classes with TTSs?

RQ2. What are Japanese pre-service teachers' perceptions of their experiences with TTSs within a compulsory English course?

RQ3. How can courses be improved according to Japanese pre-service teachers' perceptions of their experiences with TTSs?

\section{Participants}

For this study, 27 first-year undergraduate students at a national university for teacher education participated in a specially designed course and then completed a survey. According to their responses, approximately two-thirds of the students were female, and approximately half were considering a career in elementary school education. Furthermore, most respondents considered reading to be their strongest English skill, and two-thirds of them indicated that they had passed the 2 nd grade of Eiken.

\section{Implemented Course}

The participants enrolled in a compulsory English communication course for first-year undergraduate students. The course was designed by the researcher and aimed to (a) improve the English level of students who may need to work with ALTs; (b) practice a range of speaking activities on useful themes for teachers; and (c) improve their ability to ask and answer questions. For three lessons, one teacher training student (TTS) joined the class from each of the following six countries: Malawi, Morocco, Guatemala, Myanmar, Indonesia, and Gabon. Two regular exchange students, one each from Taiwan and the Czech Republic, also participated in the study. At least one regular exchange student and all six TTSs were present in each class, and all attended on a voluntary basis. In the first lesson, the Japanese students were divided into groups, the membership of which was kept the same for all three lessons. Each group talked to two students from abroad for approximately 40 minutes each, during weeks 5 , 10 , and 11. Thus, each group was able to talk to a total of six students from abroad by the end of the three lessons. Each time they met a new exchange student or TTS, everyone was required to introduce themselves and talk about the positive and negative aspects of education within his or her own country and to ask questions. In the lessons leading up to the three lessons, the Japanese students had practiced self-introductions and received information about the JET Programme and team teaching with ALTs to develop their understanding about why they needed to be able to speak English in an impromptu way. To facilitate conversation, all students were provided with paper for taking notes and a list of 23 useful words related to education in Japanese and English. Words on that list included "compulsory education," "school uniforms," "school events," "club activities," "discipline," "bullying," "teaching practice," "homework," and "cram schools." For assessment purposes, the Japanese students were required to record information about the good and bad points of education in three countries, which they then used to complete a chart to show if they were able to gain information in English successfully or not. Thus, several lessons in the course focused on preparatory and practice tasks, and these preceded the impromptu conversation practice and the assessment task.

\section{Data Collection and Analysis}

At the end of the first semester in 2019, the Japanese students completed a survey in Japanese. The survey covered basic personal information, previous experiences with foreigners, future teaching level, perceptions of their conversation experiences with TTSs and opinions regarding future courses. Nine of the survey questions comprised a 4-point Likert scale including responses for "agree," "somewhat agree," "somewhat disagree," and "disagree," and four were open-ended.

The data were analyzed in three stages. First, the survey results were calculated as percentages. Next, the comments from the open-ended questions were organized into categories to clarify general patterns in students' perceptions. Finally, benefits and recommendations for such classes were categorized and ranked.

\section{Results and Discussion}

Three questions aimed to obtain information about the pre-service teachers' past experiences using English with foreigners in order to plan suitable classes with TTSs. As can be seen in Table 1, roughly half of the students agreed or somewhat agreed that they had experienced a sustained conversation privately with a foreigner for more than 10 minutes. Although the first two items on the survey could have been worded as yes/no questions, to avoid potential student difficultly judging the length of a 10-minute conversation, a 4-point Likert scale was used. Also, it is important to note that this survey was carried 
out at the end of the course, which means that some respondents may have been referring to the new experiences and friendships they had gained during the course since at least two groups of Japanese students were observed exchanging LINE information at the end of the classes.

Table 1. Experience Talking to a Foreigner Privately for More Than 10 Minutes $(N=27)$

\begin{tabular}{lc}
\hline Response & \% of Responses \\
\hline Agree & $37 \%$ \\
Somewhat agree & $11 \%$ \\
Somewhat disagree & $22 \%$ \\
Disagree & $30 \%$ \\
\hline
\end{tabular}

Secondly, information was requested about the students' experiences speaking directly with a foreigner for more than 10 minutes during high school. Table 2 shows that one-third of the respondents agreed or somewhat agreed with this statement. This result implies that their conversations with ALTs during high school were generally limited, which means they may feel uncomfortable or have some trouble maintaining communication with foreigners in English.

Table 2. Experience Talking to a Foreigner Privately for More Than 10 Minutes During High School $(N=27)$

\begin{tabular}{lc}
\hline Response & \% of Responses \\
\hline Agree & $22.2 \%$ \\
Somewhat agree & $11.1 \%$ \\
Somewhat disagree & $22.2 \%$ \\
Disagree & $44.4 \%$ \\
\hline
\end{tabular}

Additionally, only four respondents had experienced studying in a foreign country. This result is not particularly surprising, but the overall findings of this study indicate that most respondents had few opportunities to engage in sustained conversations with a foreigner. However, this study did not include questions about foreign travel or English lessons outside of school time, which may be an additional factor worth considering.

To investigate the second research question, several survey questions aimed to obtain information about pre-service teachers' perceptions of their experiences communicating with the students from abroad. Firstly, the survey results showed that all respondents agreed or somewhat agreed that they enjoyed working in small groups with individual international students, which shows that the activity was fun. They also revealed that it was a valuable learning experience and that it helped them improve their confidence and attitude towards using and learning English. For example, students wrote that:

Up until now, I was concerned with whether or not my English was correct or not when I talked, but I became able to talk without being concerned. (Female Student A)

I was happy because I could communicate with the exchange students using English and it made me want to study more. (Female Student B)

Within the limits of my knowledge, there were many chances to speak about various things which made it a good experience. (Male Student A)

Overall, the respondents indicated reduced anxiety and successful communication were the key factors that had a positive effect on their motivation, confidence, and overall mindset.

Furthermore, the survey also revealed that over two-thirds of the respondents believed that their awareness regarding their English skills had changed from the three conversation classes. For example, two responses are provided below:

Unlike the other members in my group who were able to properly communicate their opinions with the exchange students, I was unable to do so. I want to improve my English ability. (Female Student C)

I am confident about my reading skills but I felt my listening and speaking skills are not sufficient. (Female Student D)

Despite many respondents indicating greater motivation to practice speaking in English, a few noted that they continued to find spontaneous conversations challenging for their English level. Thus, they ended the course with greater awareness of their English language proficiency and understanding of the need to practice speaking more.

The final research question aimed to determine how such courses can be improved according to students' perceptions of their communicative experiences with TTSs. To start with, the pre-service teachers were asked about the kind of activities they would like to do with TTSs, which are outlined in Table 3. Clearly, most respondents were interested in simply communicating with TTSs, but it is unclear whether they would have preferred topics other than self-introductions and discussions about 
education. Nevertheless, the results strongly confirm that pre-service teachers are keen to practice English conversation with students from abroad in compulsory communication courses.

Table 3. Preferred Activities with Teacher Training Students $(N=27)$

\begin{tabular}{lc}
\hline Activities & Total Number of Responses \\
\hline Conversation & 22 \\
Short trip & 2 \\
Language Games & 1 \\
No comment & 2 \\
\hline
\end{tabular}

The survey also included a question on the preferred number of times in a 15-week course pre-service teachers would like to have conversation lessons with TTSs. Thirteen respondents indicated that five or more lessons would be ideal and 11 answered that they would like at least three. In short, Japanese pre-service teachers appear to be keen to have impromptu conversation practice with students from abroad. Unfortunately, the respondents' request for three or more lessons may be difficult to achieve since TTSs are volunteers, who may be less willing to join more than three classes or classes in the second semester due to their scholastic commitments. Thus, despite Japanese pre-service teachers' expressed interest in communicating with TTSs, providing them with the desired number of such opportunities may be challenging.

In addition to the number of lessons to include, the topics for discussion with TTSs also require careful consideration. In this study, the conversation lessons focused on two key topics: self-introductions and education. Most respondents commented that they were able to express themselves sufficiently within the allocated conversation time, which made some students feel they had experienced successful conversations. Also, most students did not appear to struggle much despite the relatively long duration of each conversation. Several students remarked that this was partly because the TTSs, who are experienced teachers, regularly supported the flow of the conversations. Furthermore, the list of education terms provided in Japanese and English probably helped the groups move smoothly from one topic to another. If these points are taken into consideration, the topics were arguably ideal for this group of students.

\section{Conclusion}

Preparing Japanese pre-service teachers for their future workplaces and especially for team-teaching with ALTs can be challenging. Opportunities for Japanese students to interact with foreigners in Japanese universities has increased since most universities have tried to implement internationalization programs, which have often proved to be successful with the limited number of Japanese students who choose to participate in them. Also, over the past 10 years, the number of international students at higher educational institutions in Japan has increased to the point of reaching 208,901 in 2019 (JASSO, 2019), largely due to the Japanese government's efforts to internationalize universities (MEXT, 2012). However, if only a limited number of students participate in such initiatives, then the number of pre-service teachers who have had authentic interaction in English while studying at university will also continue to be limited. Thus, university educators need to find ways to ensure pre-service students can gain experiences to not only better understand and develop their language skills but also expand their understanding of other cultures and develop friendships too.

If university educators are interested in involving TTSs or other types of exchange students in their lessons, several points should be considered. Firstly, as the results of this study suggest, small group conversation practice with TTSs over three or more lessons can provide students with a good opportunity to practice using English in a spontaneous way, and such interaction can be enjoyable and motivating for the students. Secondly, courses providing opportunities for Japanese students to speak to foreigners should include preparatory lessons to enhance confidence and review communication strategies to facilitate maximum participation. Furthermore, preparing students by preselecting topics and providing a word list can assist both the Japanese students and the TTSs since they can refer to the word list to initiate or maintain conversations. Finally, teachers who implement conversation lessons with TTSs may need to substitute and talk about education from their country if a TTS is absent in order to maintain the prearranged rotation order of TTSs with the groups.

The results of this study suggest that few firstyear undergraduate students studying to be teachers have had sustained shared conversations with foreigners, but they could clearly benefit from authentic conversation practice with TTSs. For example, by experiencing successful communication with non-native English speakers using English, the participants in this study developed an awareness of 
their English skills that helped many of them develop a more positive mindset. By including such experiences in compulsory courses, more pre-service teachers will be better prepared for communicating with ALTs before they start teaching in schools.

\section{Acknowledgments}

I would like to thank Takeyoshi Takashima, who was previously appointed to the Global Education Center of Hyogo University of Teacher Education, as well as Joan Kuroda for checking the original manuscript, and Hiroshi Oshima for checking the original abstract. Furthermore, I am also grateful for Tatsuhiro Yoshida's insightful comments, too.

\section{References}

Fukuda, S., Fennelly, M., \& Luxton, R. (2013). Teamteaching Relationships in Japanese English Classrooms: An attitudinal survey. SELES Bulletin, 32, 1-15.

JASSO (2019). International Students in Japan 2018. https:// www.jasso.go.jp/en/about/statistics/intl_student/_icsFiles/afieldfile/2019/04/19/data18_brief_e.pdf

Kobayashi, A. (May 29, 2018). Why Are Fewer Young Japanese Studying Abroad? Nippon.com. https://www. nippon.com/en/currents/d00390/why-are-feweryoung-japanese-studying-abroad.html

Minetoshi, I. \& Doi, S. (2017, July 30). 小学校教員採用、 英語力で優遇 68教委中、42教委で (Shōgakkō kyōin saiyō, eigoryoku de yūgū, roku jyū hachi kyōichū, yon jyū ni kyōi de) [Elementary School Teacher Recruitment, Preferential Treatment from 42 out of 68 BOEs], Asahi Shinbun. https://www.asahi.com/articles/ ASK7P64P5K7PUTIL05H.html

Ministry of Education, Culture, Sports, Science, and Technology (MEXT). (2012). Higher Education in Japan. https://www.mext.go.jp/en/policy/ education/highered/title03/detail03/__icsFiles/ afieldfile/2012/06/19/1302653_1.pdf

Ministry of Education, Culture, Sports, Science and Technology (MEXT). (2017a). 平成28年度「英語教育実施 状況調査」(中学・高等学校関係) (Heisei 28 nendo “eigo kyōiku jisshi jōkyō chōsa" chūgaku kōtō gakkō kankei) [2016 Survey into the Status of Implementation of English Education]. http://www.mext. go.jp/ component/a_menu/education/detail/__icsFiles/ afieldfile/2017/04/07/1384236_01_1.pdf

Ministry of Education, Culture, Sports, Science and Technology (MEXT). (2017b). 中学校学習指導要領 ( 平成29年 告示) 解説 外国語編 (Chūgakkō gakushū shidō yōryō "Heisei 29 nen kokukji" kaisetsu gaikokugohen) [Junior High School Course of Study Guidelines]. http://www.mext.go.jp/component/a menu/ education/ micro_detail/__icsFiles/ afieldfile/2019/03/18/1413522_002.pdf
Ministry of Education, Culture, Sports, Science, and Technology (MEXT). (2018). 小学校学習指導要領 (平成 29年告示) 解説 (Shōgakkō gakushū shidō yōryō "Heisei 29 nen kokukji" kaisetsu) [Elementary School Course of Study Guidelines (2017)]. Kairyukan.

Ministry of Education, Culture, Sports, Science, and Technology (MEXT). (2019). Application Guidelines Japanese Government (MEXT) Scholarship for 2020 (Teacher Training Students). https://www.mext.go.jp/ content/1423052_7_2_1.pdf

Ministry of Education, Culture, Sports, Science, and Technology (MEXT). (n.d.). About Tobitate! (Leap for Tomorrow) Study Abroad Initiative. https://tobitate. mext.go.jp/about/english.html

OECD (2018), "Japan", in Education at a Glance 2018: OECD Indicators. OECD Publishing. https://doi. org/10.1787/eag-2018-54-en

Rushton, A. (2019). Matching communicative language teaching to a Japanese EFL context with the Principled Communicative Approach. Kobe Kaisei Review, 57, 33-41.

Tanabe, N. (2011). High school teachers' impressions about their use of English in classes: A questionnaire survey after the announcement of the New Course of Study. JACET Chügoku-Shikoku Chapter Research Bulletin, 8, 27-39.

Tsuji, S., \& Swanson, M. R. (2019). Developing the speaking proficiency of non-native English teachers. Shitennoji University Bulletin, 67, 131-146.

Yoshida, T., Kondo, A., Tada, W., Narumi, T., \& Yamamoto, D. (2020). 文部科学省委託事業「中学校・高等 学校における英語教育の抜本的改善のための指導方法等に 関する実証研究」最終報告書 (Monbu kagakushōitaku jigyō “ chūgakkō kōtō gakkō niokeru eigo kyōiku no bappon teki kaizen no tame no shidō hōhōtō nikansuru jisshō kenkyū "saishū hōkokusho) [The Final Report of a MEXT Commissioned Project on Empirical Research into the Radical Improvement of English Education in Junior and Senior High Schools]. Center for R\&D in Innovative English Language Teaching, Hyogo University of Teacher Education.

Wendy Tada is an Associate Professor at Hyogo University of Teacher Education. She earned a Master in Applied Linguistics for Language Teachers from Monash University, a Graduate Diploma in Education from the University of Adelaide, Australia, and completed a CELTA certificate

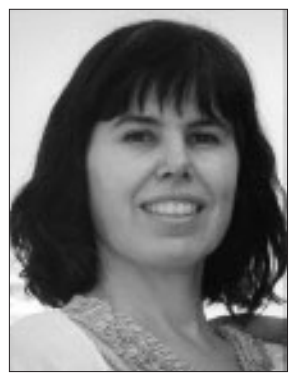
at Language Resources, Japan.

Her research interests include early EFL literacy development and second language acquisition. She is also busy raising a bilingual 8-year-old girl. 